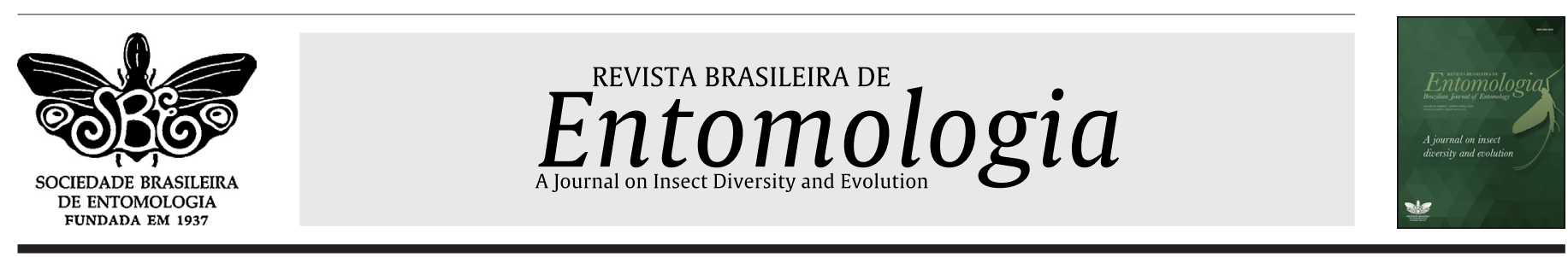

\title{
A new species of Thraulodes Ulmer (Ephemeroptera: Leptophlebiidae), with additional data on the anatomy of the reproductive tract
}

\author{
Isabel Cristina Hernández Cortes ${ }^{1,2}$ (D), Lucimar Gomes Dias² (iD, \\ Vinícius Albano Araújo ${ }^{*}$ \\ ${ }^{1}$ Universidade Federal de Viçosa, Departamento de Entomologia, Museu de Entomologia, Viçosa, MG, Brasil. \\ ${ }^{2}$ Universidad de Caldas, Facultad de Ciencias Exactas y Naturales, Grupo de Investigación Bionat, Manizales, Caldas, Colombia. \\ ${ }^{3}$ Universidade Federal do Rio de Janeiro (UFRJ), Instituto de Biodiversidade e Sustentabilidade (NUPEM), Macaé, RJ, Brasil. \\ urn:lsid:zoobank.org:pub:1E91B29D-64D7-4574-B103-FA2835E6E490
}

\section{A R T I C L E I N F O}

Article history:

Received 15 February 2021

Accepted 15 March 2021

Available online 14 April 2021

Associate Editor: Fabio Quinteiro

\section{Keywords:}

Mayflies

Reproductive morphology

Taxonomy

Colombia

Caldas

\begin{abstract}
A B S T R A C T
A new species of Thraulodes Ulmer 1920 is described based on nymphs and imagos from Tapias river, Caldas department, Colombia. The mature nymphs were reared until the emergence of the imagos. Thraulodes latinus sp. n. can be distinguished from other species of the genus by: In males, the forewing without cross veins basal to bullae and with 11-14 cross veins distal to bullae, abdominal and legs color pattern, styliger plate redounded, with a long and digitiform median projection and shape of penes with apicolateral area forming an "ear-like" projection. In nymphs, the claws with eight denticles and the general coloration pattern. Additionally, data on the anatomy of the reproductive tract of both the male and female imago of the new species are presented.
\end{abstract}

\section{Introduction}

Thraulodes Ulmer is one of the most diverse genera of Ephemeroptera worldwide, with 80 species (Barber-James et al., 2008; Sartori and Brittain, 2015; Kluge, 2020; Pérez et al., 2020). The genus has a Pan-American distribution, extending from central Argentina to the Nearctic Region (southern United States) and its geographic range is between $30-45^{\circ} \mathrm{N}$ and $25-28^{\circ} \mathrm{S}$ (Traver and Edmunds Junior, 1967; Allen and Brusca, 1978; Domínguez, 1987; McCafferty, 1998; Domínguez et al., 2006; Barber-James et al., 2008; Lima et al., 2013). The origin of Thraulodes is austral (Allen and Brusca, 1978; Allen and Murvosh, 1983; McCafferty, 1998) and within the Leptophlebiidae family the genus is one of the most abundant, with a wide distribution in South America (Domínguez et al., 2006). In this region, the genus is reported from Colombia, Venezuela, Ecuador, Guyana, Peru, Brazil, Uruguay, Chile, Argentina and Bolivia (Traver and Edmunds Junior, 1967; Domínguez, 1986, 1987; Hubbard et al., 1992; Giordano and Domínguez, 2005).

\footnotetext{
* Corresponding author.

E-mail: vialbano@gmail.com (V.A. Araújo).
}

The nymphs of Thraulodes are found in a wide range of altitudes with some species reported from 400 to $1700 \mathrm{~m}$, generally associated with stony bottoms and well aerated waters, although some tolerate some fluctuations in temperature and oxygen (Domínguez et al., 2006; Flowers, 2009; Gonçalves et al., 2013). At present, about 80 species of Thraulodes are described, in South America the genus is represented by 51 species, the most known only from adult stage, a common scenario for the genus (Domínguez et al., 2006; Salles, 2006; Flowers, 2009; Gonçalves et al., 2010, 2013; Medina and Pérez, 2010; Mariano et al., 2011; Barber-James et al., 2013; Lima et al., 2013; Souto et al., 2014; Zúñiga et al., 2015; Boldrini et al., 2018; Campos and Mariano, 2019; Francischetti et al., 2019; Kluge, 2020; Pérez et al., 2020). In Colombia, only four species are documented: T. colombiae Walker, 1853; T. laetus Eaton, 1884; T. papiliones Traver and Edmunds, 1967 and T. insular Zúñiga et al., 2015.

In this work, a new species of Thraulodes is described based on nymphs and adults (male and female) from Caldas department, Colombia. In addition, data about the reproductive tract anatomy of nymph, subimago and adult of the new species are presented. 


\section{Material and methods}

Specimens were collected in stony bottoms in Tapias river in Neira, Caldas department, Colombia ( $5^{\circ} 11^{\prime} 21.5^{\prime \prime} \mathrm{N} 75^{\circ} 29^{\prime} 39.8$ "W). The nymphs studied in this work were collected with Surber net $(30 \times 30 \mathrm{~cm}$, mesh size $250 \mathrm{~mm}$ ) and stored in $90 \%$ alcohol. The mature nymphs were reared in the Laboratorio de Colecciones Biológicas of the Universidad de Caldas to associate with adults.

The type material is deposited in the Colección Entomológica del Programa de Biología de la Universidad de Caldas (CEBUC) and Museu de Entomologia - Universidade Federal de Vicosa (UFVB). For the thorax we adopted the terminology proposed by Kluge (1994) and for the genitalia of the male imago Traver and Edmunds Junior (1967) modified by Domínguez et al. (2006). The drawings were made in Adobe Illustrator CC $®$ based on photographs and prepared based on Coleman (2003, 2006, 2009), plates we elaborated on Adobe Photoshop CC 2019.

\section{Anatomy of the reproductive tract}

Thirteen individuals in different stages (nymph, subimago and adult) of the new species of Thraulodes were dissected. The insects were cryo-anesthetized, and their reproductive tracts were dissected in $0.1 \mathrm{M}$ sodium chloride. For anatomical analysis, freshly fixed reproductive tracts were placed on a histological slide and photographed unstained with a Leica M205 C light microscope.

\section{Thraulodes latinus Cortes, Dias and Araújo sp. nov.}

(Figs. 1-4)

Diagnosis: The imago of Thraulodes latinus sp. nov. can be distinguished from the other species of the genus by the following combination of characters: 1) forewing without cross veins basal to bullae (Fig. 2A); 2) costal and subcostal areas of forewing translucent; 3 ) femora of forelegs with an apical transversal orange band and with an orange-brown medial macula on the basal half (Fig. 1C);4) abdominal coloration pattern as in Figure 1B, with terga II-VI whitishtranslucent with an anterolateral dark triangular spot, and terga VII-X reddish-brown (Fig. 1A-B); 5) styliger plate with a long and digitiform posterior median projection (Figs. 1F and 2C); 6) penes with apicolateral area forming an "ear-like" projection and with a straight and long thin spine, recurved folds parallel to the internal margin, and lateral pocket present (Figs. 1F-G and 2D-E).

Male imago (Figs. 1-2). Holotype male imago. Body length: 7.4$7.6 \mathrm{~mm}$; forewing length: 8.4-9.3 $\mathrm{mm}$; hind wing length: $1.8-2.1 \mathrm{~mm}$. General coloration white with brown and reddish areas, some abdominal segments translucent with dark grey spots. Head: Coloration brown; scape and pedicel dark brown, flagellum white shaded with light brown. Area between ocelli brown; ocelli white surrounded by a brown ring at base; upper portion of eyes brown, lower portion dark brown (Fig. 1A-B). Thorax: Pronotum light brown with some whitish areas (Fig. 1A-B); mesonotum dark brown and reddish, with lateral and hind margins white (Fig. 1A-B); metanotum dark brown (Fig. 1A-B); prosternum white; mesosternum brown, with hind margin of basisternum white; metasternum light brown with dark brown areas. Wings: Membrane of wings hyaline with black stain at base, with longitudinal and cross veins light brown or translucent. Costal area with 11-14 cross veins distal to bullae and without cross veins basal to bullae. Subcostal area with 7-11 cross veins distal to bullae and 4-5 cross veins basal to bullae (Fig. 2A); membrane of hind wing hyaline, with a black stain at the base, longitudinal and cross veins light yellow or translucent and with 5 cross veins (Fig. 2B). Foreleg: coxa and trochanter whitish- translucent; femur whitish with an orange band at the apical half, this band present its apical and lateral margins dark brown, and with an orange-brown macula on basal half; tibia orange-translucent with apical region blackish; tarsi whitish shaded slightly with light orange; tarsal claws light brown (Fig. 1C). Middle leg: coxa dark brown, trochanter whitish-translucent, femur with basal $2 / 3$ whitish, with a brownorange spot the basal half, and with an orange band on apical $1 / 3$, lateral margin dark brown; tibia orange-translucent, tarsi and claws as in foreleg (Fig. 1D). Hind leg: the same as the middle leg (Fig. 1E). Abdomen (Figs. 1A-B): Tergum I dark brown with whitish areas; terga II-VI whitish-translucent shaded with light brown, with anterolateral triangular black spot, less marked on tergum II; Terga VII and IX-X dark reddish brown with lateral posterior region whitish; tergum VIII whitish with stain triangular dark reddish brown in median region; terga VIII and IX with dark brown stripes in lateral margin; spiracle area blackish; Sternites I-VI translucent, VII with posterior region whitish and VIII-IX whitish. Genitalia: styliger plate white translucent, with lateral margins rounded; posterior margin rounded and with posterior median digitiform long projection; Forceps whitish with lateral margin brown, maximum width of segment III of forceps 0.7 times the width of segment II (Figs. 1F and 2C). Penes brown, relatively long and broad, with external margin forming a whitish-translucent lateral pocket; recurved folds parallel to the internal margin; with a straight and long thin spine (at least 2.0x the width of penes as Fig. 1G); apicolateral area forming an "ear-like" projection well developed (Figs. 1F and 2D-E).

Female imago (Fig. 3). Body length: 6.5- $6.9 \mathrm{~mm}$; forewing length: 9.4-9.6 mm; hind wing length: $1.9-2.0 \mathrm{~mm}$. General coloration reddish brown with some areas whitish. General characteristics similar to the male. Head: brown; ocelli whitish surrounded by a black ring. eyes dark brown (Fig. 3A). Abdomen: Terga I-VI reddish brown; terga VII-X and sternites I-IX similar to the male (Fig. 3A-C). Apex of sternum X with a V-shaped cleft (Fig. 3C).

Mature nymph (male) (Fig.4): Body length: 7.2-7.8 mm; caudal filaments: $10.2 \mathrm{~mm}$. General coloration light yellow with dark brown stains (Fig. 4A). Head: coloration dark brown with anterolateral and posterior areas yellowish. Upper portion of eyes dark brown, lower portion blackwish. Ocelli white, area between ocelli and eyes shaded of dark brown. Antennae with scape, pedicel and flagellum light yellowtranslucent. Mouthparts: Labrum with dorsal surface brown yellowish (Fig. 4B), with an apical row of short setae and a subapical row of long setae; apical margin with 5 denticles slightly marked. Clypeus brown. Mandibles strongly curved, with dorsal surface light yellow shaded with grey to brown (Fig. 4C-D); row of whitish bristles in apical half of outer margin; incisors and molar dark brown-yellowish; prostheca whitish to light yellowish. Left mandible with three apical denticles on the inner and outer incisor; prostheca with basal spur and pectinate setae (Fig. 4C). Right mandible with two apical and three apical denticles on inner and outer incisors, respectively; left prostheca similar to right prostheca (Fig. 4D). Maxilla whitish-translucent shaded with light brown (Fig. 4F-G); apical margin with row of long simple setae and subapical row of pectinate setae; inner margin bordered by long setae; posterior margin with short setae; maxillary palp with outer margin bordered by long setae, denser at the apical margin of segment III. Hypopharynx yelowish-translucent shaded with light brown and grey (Fig. 4E); superlingua with apical area of lateral arms slightly shaded with blackish and with long row of brown setae in apical margin; lingua curved and narrow, apical margin with short setae. Labium whitish-translucent slightly shaded with yellowish (Fig. 4H); glossae with short setae on ventral surface, and with strong and short setae on lateral margins; paraglossae with short setae in apical one third, and with fields of long setae in outer margin inwardly directed; labial palpi with long setae on outer margin, short and sparces on segments 

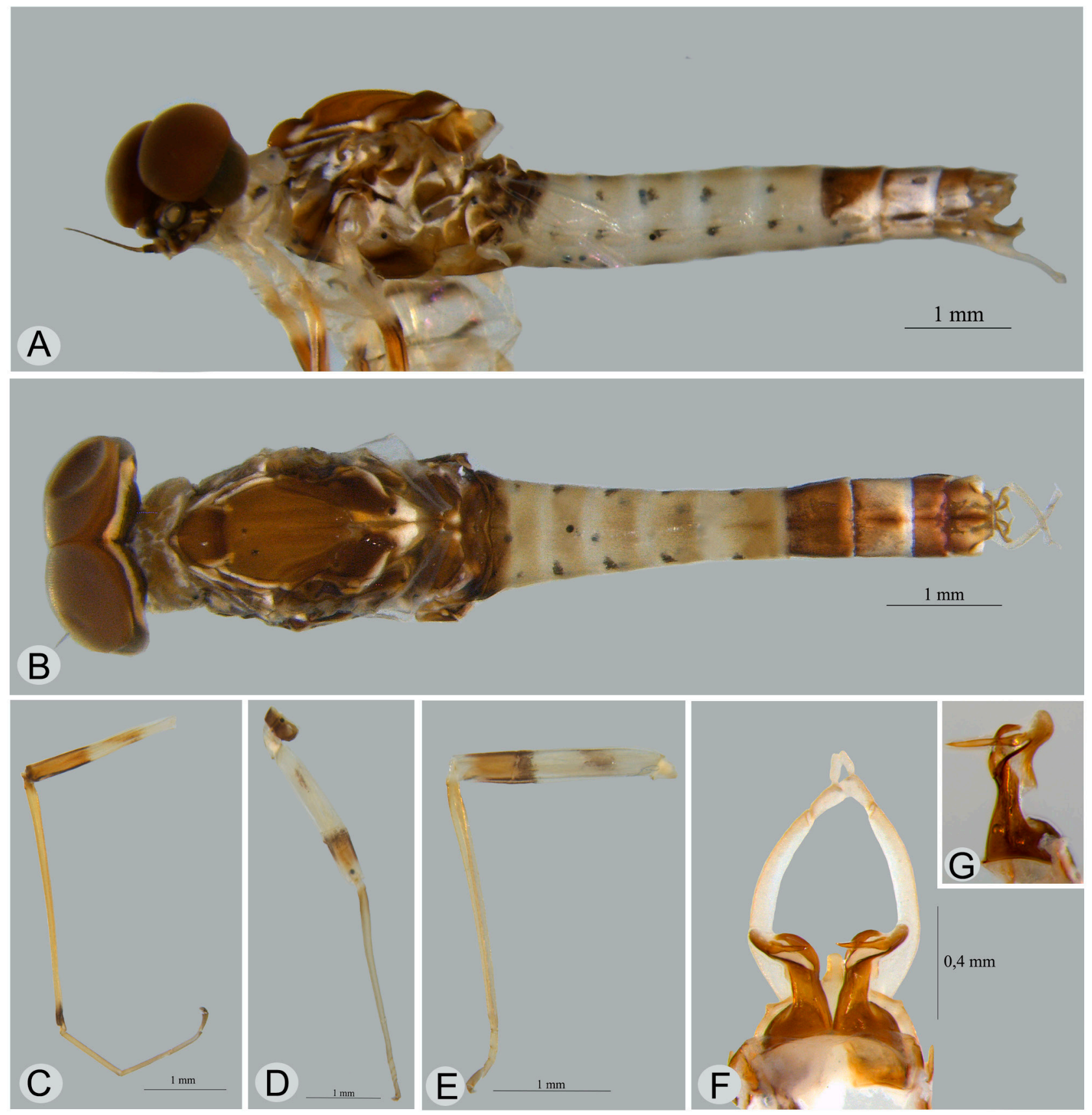

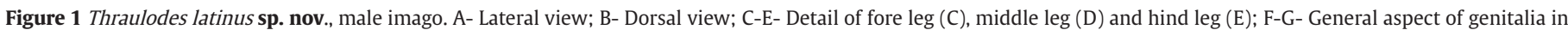
dorsal view (F) and lateral view (G).

II and III (Fig. 4H). Thorax: Pronotum light yellow, with anterior region dark brown; mesonotum dark brown with some areas light yellowish (Fig. 4A). Thoracic sterna whitish, slightly shaded with yellow. Legs: coxae light brown, with outer margin bordered with long setae. Foreleg with femur light yellow, dorsal surface with short spatulate setae, basal half light brown and an apical dark brown spot; outer margin with row of numerous long simple setae and short spatulate setae and with few long spatulate setae; inner margin with few long simple setae and with numerous short spine like setae. Tibia light yellowish, outer margin with row of numerous long simple setae; dorsal surface with row of strong spatulate setae, few long and numerous short. Tarsus light yellowish shaded with light brown, with simple setae on outer margin; claws with eight denticles, apical denticle twice as large as the subapical denticles (Fig. 4A). Middle and hind femora light yellowish, with basal half light brown and with a longitudinal yellowish macula on outer and apical spot light brown; setae similar to fore femur, except for absence and scarcity of setae on inner margin of middle and hind femora, respectively. Tibiae light yellow, with row of long and numerous setae on outer margin, more abundant on hind tibia; inner margin with short spine like setae. Tarsi and claws similar to fore leg. Abdomen: Terga I-VIII dark brown, except median region of terga IV and V light yellow; terga II-VI with blackish anterolateral spots; terga IX and X light yellow (Fig. 4A). Gills narrow, hyaline, with blackish tracheas lacking lateral branches; width of tracheae subequal to half the width of entire gill. Caudal filaments light yellowish with a ring of short erect setae on each segment (Fig. 4A).

Mature nymph (female): Share the same morphological characters and coloration pattern describe from male nymph, except by: body 

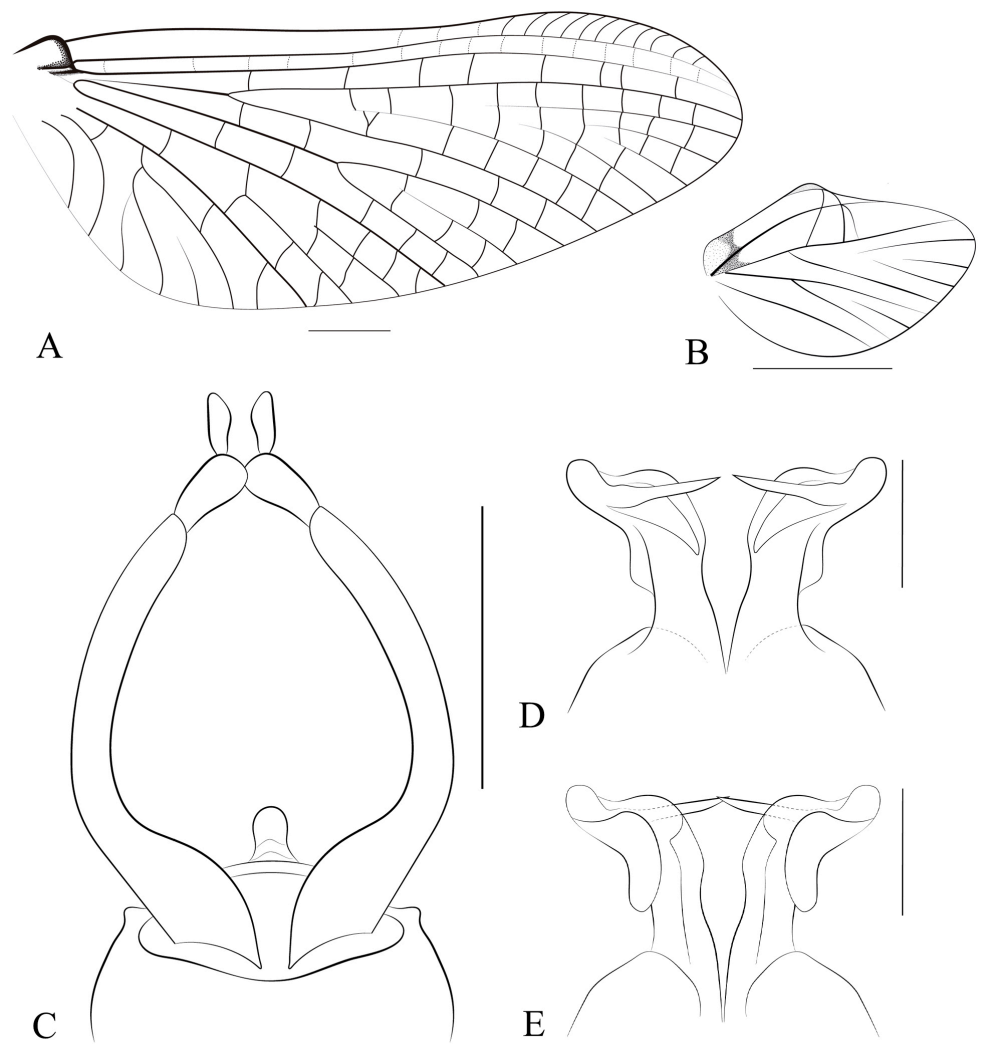

Figure 2 Thraulodes latinus sp. nov., male imago. A- Fore wing; B- Hind wing; C- Styliger plate, ventral view; D-E- Detail penes, dorsal view (D) and ventral view (E). Bars: A-B $=1 \mathrm{~mm} ; \mathrm{C}=0.04 \mathrm{~mm} ; \mathrm{D}-\mathrm{E}=0.02 \mathrm{~mm}$.
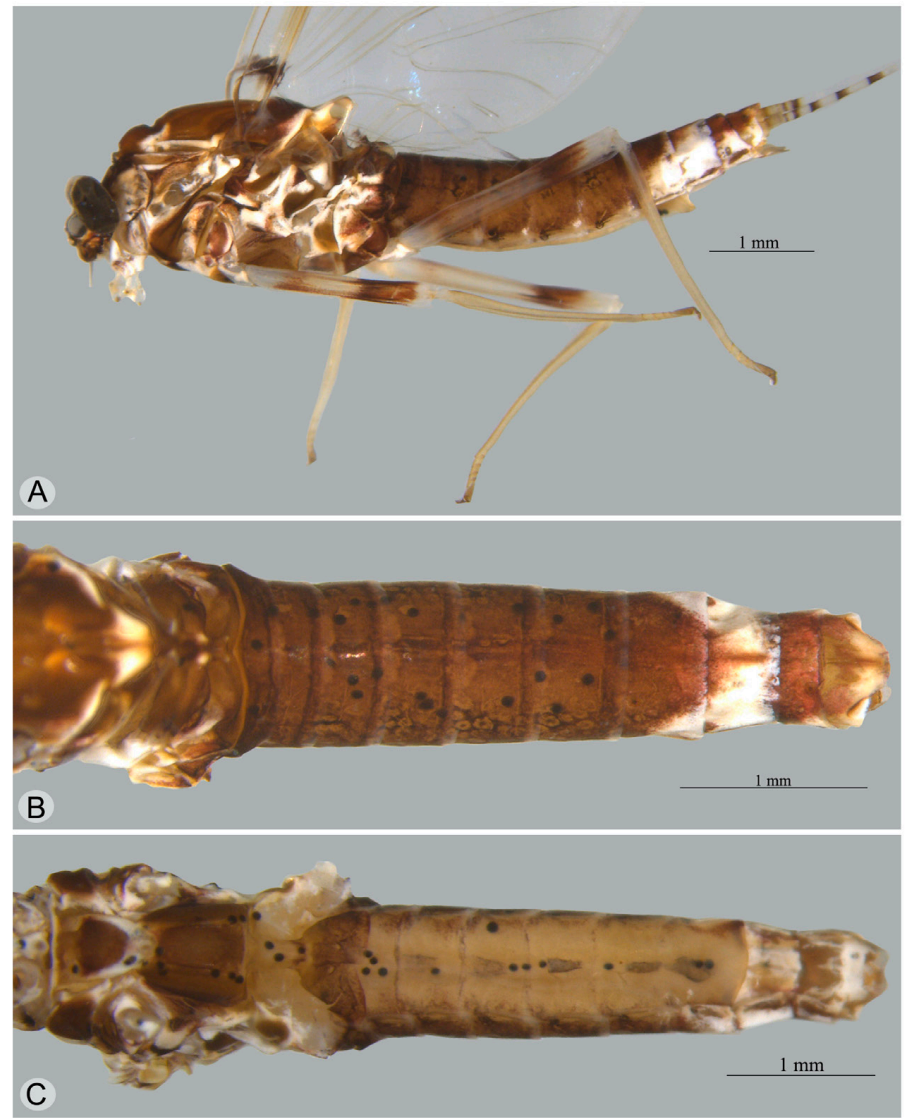

Figure 3 Thraulodes latinus sp. nov., female imago. A- Lateral view; B-C- Abdomen, in dorsal view (B) and ventral view (C). 


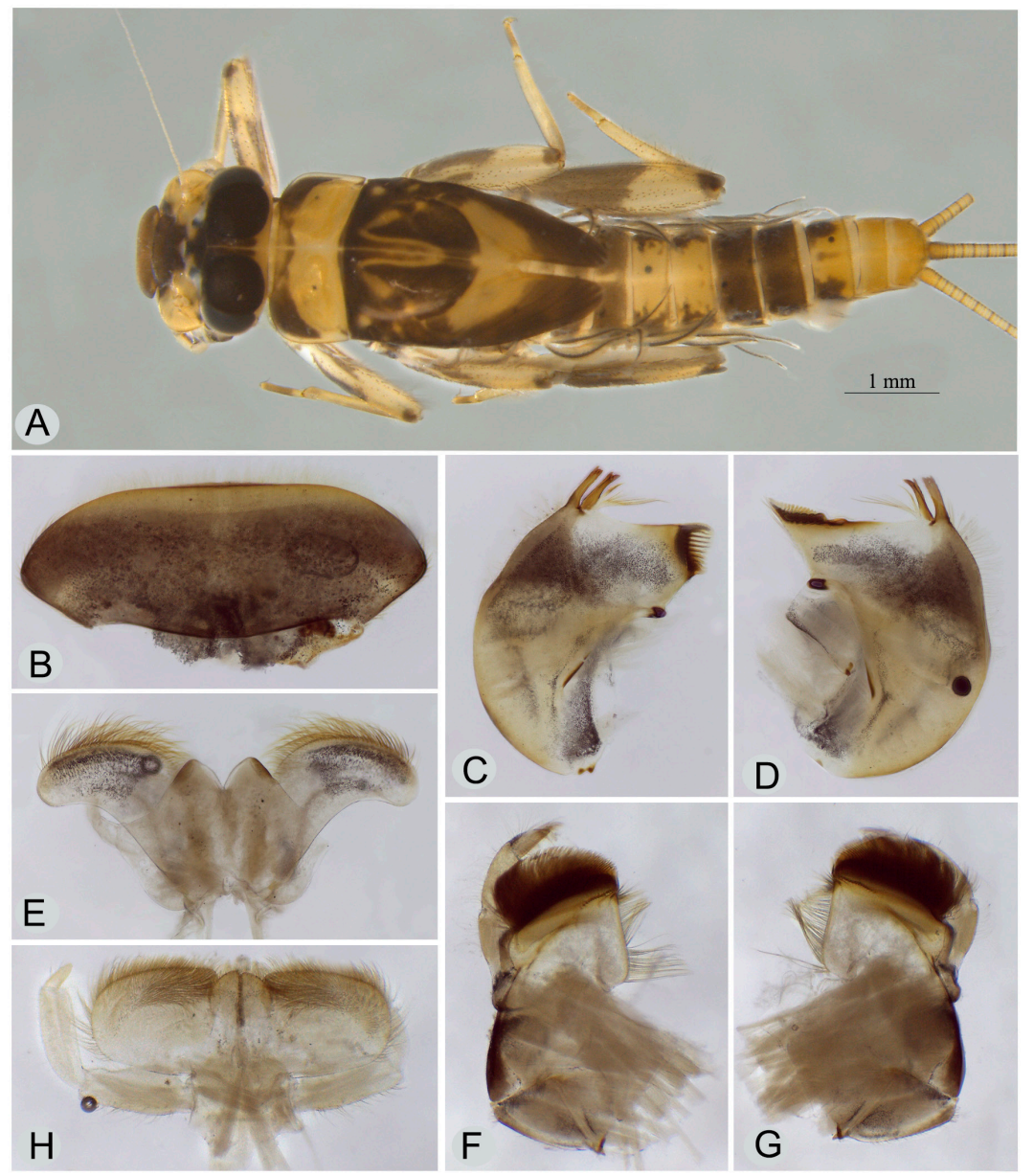

Figure 4 Thraulodes latinus sp. nov., nymph. A- Habitus; B-H- Mouthparts, labrum (B); left mandible (C); right mandible (D); hypopharynx (E); maxilla (F-G) and labium (H).

length (female nymphs: 6.9-9.2 $\mathrm{mm}$ ) and eyes coloration, that is blackish in female nymphs.

Type material: Holotype: male imago, Colombia, Caldas department; Neira municipality; stony bottoms in Tapias river ( $5^{\circ} 11^{\prime 2} 21.5^{\prime \prime} \mathrm{N} 75^{\circ} 29^{\prime} 39.8^{\prime \prime} \mathrm{W}$, 1700 m.a.s.l.), ISHC, LGD, VAA colls. Paratypes: 2 male imagos, 2 female imagos and 2 nymphs, same data as holotype (CEBUC) and 1 male imago, 1 female imago and 1 nymph, same data as holotype (UFVB).

Other examined material: 20 nymphs, 6 male imagos, 5 females imagos and 10 subimagos, same data as holotype.

Biology: The nymphs were found on stony bottoms of streams in areas of moderate current, and with riparian vegetation.

Etimology: The epithet is a reference to wide distribution of the genus in Latin America.

Anatomy of the reproductive tract: The reproductive tract in males of Thraulodes latinussp. nov. are formed by a pair of testes, each ending in a deferent duct, a region that also stores spermatozoa (Fig. 5A-D). The anatomy of the reproductive tract showed differences between the stages of nymphs for subimago and adults. In mature nymphs the testes were developed, while the deferent ducts were thin, measuring an average of $80 \mu \mathrm{m}$ in diameter and with the lumen apparently empty (Fig. 5A). In subimagos (Fig. 5B) and adults (Fig. 5C-D) the testicles were degenerated and the vas deferens dilated, measuring, on average, $100 \mu \mathrm{m}$ (subimago) and $130 \mu \mathrm{m}$ (adults) in diameter and with the lumen full of spermatozoa. The two mesodermal spermatic ducts flow separately into the gonopores (Fig. 5C-D) between segments IX and X. In females, a pair of ovaries was observed, each with a single ovarian follicle (Fig. 6A). Each ovarian follicle connects to a lateral oviduct and they come together to form a common oviduct (Fig. 6B). In subimago and adults, the ovarian follicles reach the thoracic tagma and are full of oocytes, filling a large part of the body cavity. The oocytes were rectangular and measured approximately $150 \mu \mathrm{m}$ length and $80 \mu \mathrm{m}$ width (Fig. 6C).

\section{Discussion}

The coloration pattern of the male imago of Thraulodes latinus sp. nov. resembles Thraulodes eduardorum Medina and Pérez, 2010, nevertheless, T. eduardorum presents 9-11 cross veins distal to bullae and 3-5 basal to bulla (Pérez and Nieto, 2016), while in T. latinus sp. nov. 11-14 cross veins are present distal to bullae and the cross veins basal to bulla are absent. Additionally, the posterior margin of the styliger plate of T. eduardorum straight and the median projection is short, while in T. latinus sp. nov. the posterior margin is rounded and the median projection long and digitiform; besides, these characteristics the ear like apicolateral area of the penes is more developed in T. latinus sp. nov. when compared to T. eduardorum.

In the nymphal stage Thraulodes latinus sp. nov. resembles Thraulodes telegraphicus Needham \& Murphy 1924, due to body pattern coloration (in Figure 66 of Kluge, 2020). In T. latinus sp. nov. the anterior margin of pronotum is completely brown, while in T. telegraphicus the brown coloration is restricted to the anterolateral margin (Kluge, 2020). In addition, the basal region of the wingpads of T. latinus sp. nov. is washed with dark brown, while in T. telegraphicus this region is yellowish (in Figure 66 of Kluge, 2020); and in T. latinus sp. nov. 

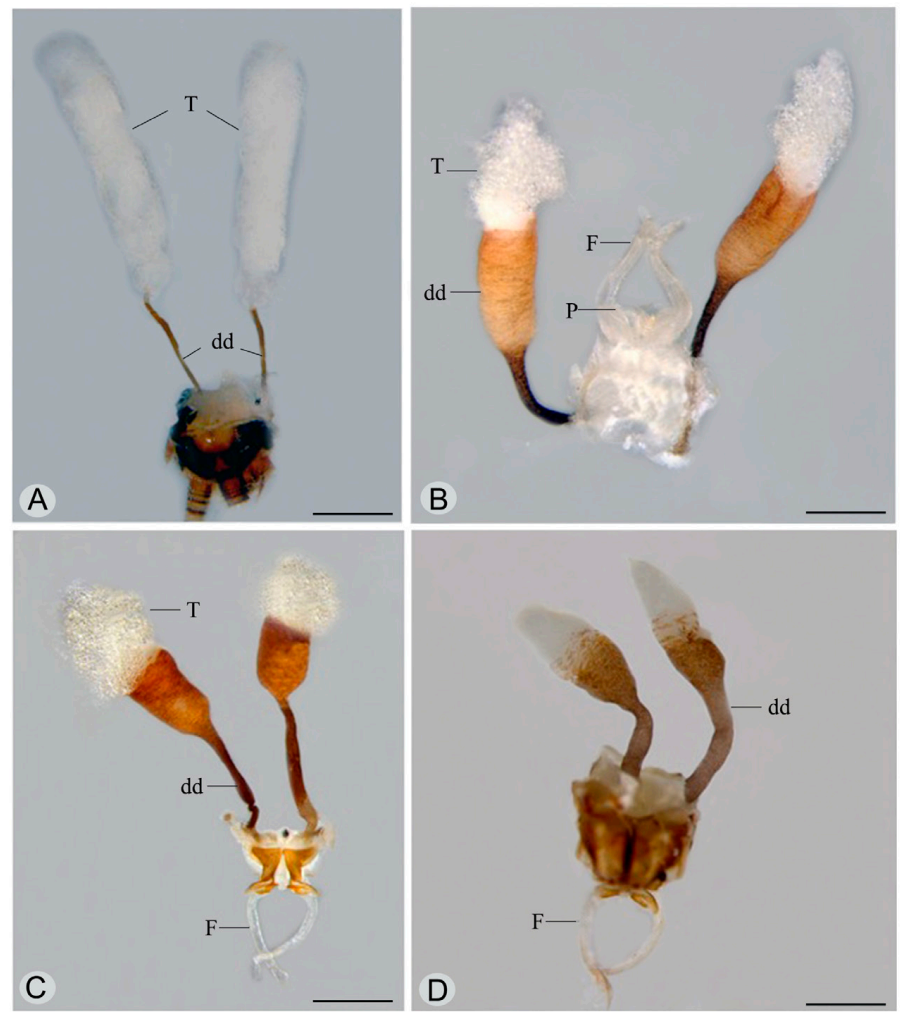

Figure 5 Male reproductive tract of the Thraulodes latinus sp. nov. A- Mature nymph showed the testes (T) and deferent ducts (dd) still empty. Subimago (B) and adults (C-D) showed the degenerate testes (T), deferent ducts (dd) full of spermatozoa, penises ( $\mathrm{p}$ ) and forceps (f). Bars: $\mathrm{A}=0.7 \mathrm{~mm}$ and $\mathrm{B}-\mathrm{D}=0.5 \mathrm{~mm}$.

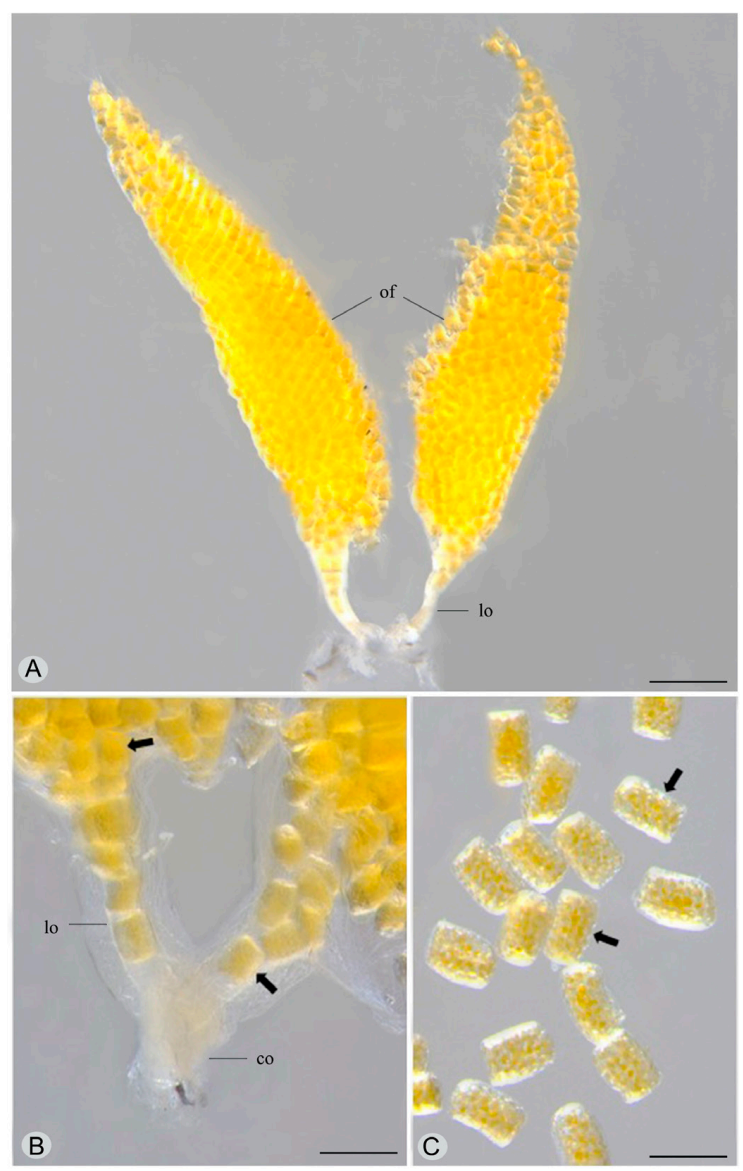

Figure 6 Female reproductive tract of the Thraulodes latinus sp. nov. A- Reproductive tract of an adult female showing the ovarian follicles (of) full of eggs and the lateral oviduct (lo). In (B) detail of the lateral oviduct (la) and common oviduct (co). The arrows indicate the eggs in the ovarian follicles and in the lateral oviduct. C- Rectangular oocytes (arrow) in mature females. Bars: $\mathrm{A}=400 \mu \mathrm{m}$ and $\mathrm{B}-\mathrm{C}=160 \mu \mathrm{m}$. 
there is a dark brown spot on the anterolateral margin of terga IV-V which extends to the posterolateral margin, while in T. telegraphicus it is restricted to the anterolateral margin (Kluge, 2020).

Few studies have described the anatomy of the reproductive system in maylflies, possibly due to the short time of the adult reproductive phase, which usually occurs at night and within a few hours (Peckarsky et al. 2002). In these primitive insects, the reproductive tract is similar among the species studied, including for Leptophlebiidae (Brito et al., 2012), in which males lack accessory glands, and the deferent ducts open directly on the penis in paired genital openings, with a single ejaculatory duct (Soldán, 1979; Brito et al., 2012) and, females, present unique ovarioles and absence of spermatheca (Sartori and Brittain, 2015).

\section{Acknowledgements}

We thank the Universidad de Caldas for the infrastructure for laboratory work and Universidade Federal do Rio de Janeiro (UFRJ) for supporting the visit of VAA to Colombia. We also thank to Jhon Faber Marulanda for assistance with sampling specimens in Tapias river, Neira.

\section{Conflicts of interest}

The authors declare no conflicts of interest.

\section{Author contribution statement}

All authors carried out the field work and rearing of mature nymphs in laboratory. ICHC and LGD carried out the taxonomic work, dissections and photographs and VAA the reproductive morphology work. ICHC realized illustrations and the preparation of plates. All authors participated in the final redaction and critically review of the manuscript.

\section{References}

Allen, R. K., Brusca, R. C., 1978. Generic revisions of mayfly nymphs. II. Thraulodes in North and Central America. Can. Entomol. 110, 413433. https://doi.org/10.4039/ent110413-4.

Allen, R. K., Murvosh, C. M., 1983. Taxonomy and zoogeography of the mayflies (Ephemeroptera: Insecta) of Baja California. Ann. Entomol. Soc. Am. 76, 425-433. https://doi.org/10.1093/aesa/76.3.425.

Barber-James, H. M., Gattolliat, J. L., Sartori, M., Hubbard, M. D., 2008. Global diversity of mayflies (Ephemeroptera, Insecta) in freshwater. Hydrobiologia 595, 339-350. https://doi.org/10.1007/s10750-0079028-y.

Barber-James, H., Sartori, M., Gattolliat, J. L., Webb, J., 2013. World Checklist of Freshwater Ephemeroptera Species. Available in: http:// fada.biodiversity.be/group/show/35 (accessed 11 January 2021).

Boldrini, R., Dantas, H. A. T. P., Lima, L. R. C., 2018. New species and new record of Thraulodes Ulmer, 1920 (Ephemeroptera: Leptophlebiidae: Atalophlebiinae) from Brazil. Zootaxa 4527, 277-280. https://doi. org/10.11646/zootaxa.4527.2.8.

Brito, P., Salles, F. F., Dolder, H., 2012. Morphology of male reproductive systems in Ephemeroptera: intrinsic musculature. Neotrop. Entomol. 41, 306-310. https://doi.org/10.1007/s13744-012-0039-7.

Campos, R., Mariano, R., 2019. New species of Thraulodes Ulmer, 1920 (Ephemeroptera: Leptophlebiidae: Atalophlebiinae) from Northeastern Brazil. Zootaxa 4565 (2), 213-222. https://doi. org/10.11646/zootaxa.4565.2.5.
Coleman, C. O., 2003. "Digital inking": how to make perfect line drawings on computers. Org. Divers. Evol. 3 (4), 303-304. https:// doi.org/10.1078/1439-6092-00081.

Coleman, C. O., 2006. Substituting time-consuming pencil drawings in arthropod taxonomy using stacks of digital photographs. Zootaxa 1360 (1), 61-68. https://doi.org/10.11646/zootaxa.1360.1.4.

Coleman, C. O., 2009. Drawing setae the digital way. Zoosyst. Evol. 85 (2), 305-310. https://doi.org/10.1002/zoos.200900008.

Domínguez, E., 1986. Thraulodes bolivianus, una nueva especie de la familia Leptophlebiidae, Insecta: Ephemeroptera) de Bolivia. Acta Zool. Lilloana 38 (2), 149-153.

Domínguez, E., 1987. El género Thraulodes(Ephemeroptera: Leptophlebiidae) en la República Argentina. Acta Zool. Lilloana 39, 47-65.

Domínguez, E., Molineri, C., Pescador, M., Hubbard, M. D., Nieto, C., 2006. Aquatic Biodiversity in Latin America, Vol. 1: Ephemeroptera of South America. Pensoft Publishers, Sofia.

Eaton, A. E., 1884. A revisional monograph of recent Ephemeridae or mayflies. Part 2. Trans. Linn. Soc. Lond. Ser. 23, 77-152. https://doi. org/10.1111/j.1096-3642.1883.tb01550b.x.

Flowers, R. W., 2009. A new species of Thraulodes (Ephemeroptera: Leptophlebiidae, Atalophlebiinae) from a highly altered river in western Ecuador.Zootaxa 2052 (1), 55-61. https://doi.org/10.11646/ zootaxa.2052.1.4.

Francischetti, C. N., Raymundo, T. S., Salles, F. F., 2019. A new species of Thraulodes Ulmer (Ephemeroptera: Leptophlebiidae) from the Atlantic Forests of Southeastern Brazil. Zoosymposia 16 (1), 88-95. https://doi.org/10.11646/zoosymposia.16.1.9.

Giordano, J. A., Domínguez, E., 2005. Thraulodes basimaculatus sp. n., a new species of mayfly from Bolivia: (Ephemeroptera: Leptophlebiidae: Atalophlebiinae). Zootaxa 1040, 45-48. https://doi.org/10.11646/ zootaxa.1040.1.4.

Gonçalves, I. C., Da-Silva, E. R., Nessimian, J. L., 2010. A new species of Thraulodes Ulmer (Ephemeroptera: Leptophlebiidae) from Southeastern Brazil.Zootaxa 2438 (1), 61-68. https://doi.org/10.11646/ zootaxa.2438.1.4.

Gonçalves, I. G., Da-Silva, E. R., Nessimian, J. L., 2013. Thraulodes bonito sp. nov. (Ephemeroptera: Leptophlebiidae) from Rio de Janeiro dept, Southeastern Brazil. Zootaxa 3669 (2), 153-158. https://doi. org/10.11646/zootaxa.3669.2.6.

Hubbard, M. D., Domínguez, E., Pescador, M. L., 1992. Los Ephemeropteros de la República Argentina: un Catálogo. Rev. Soc. Entomol. Argent. 50, 201-240.

Kluge, N. J., 1994. Pterothorax structure of mayflies (Ephemeroptera) and its use in systematics. Bull. Soc. Entomol. Fr. 99 (1), 41-61.

Kluge, N. J., 2020. Systematic position of Thraulodes Ulmer 1920 (Ephemeroptera: Leptophlebiidae) and descriptions of new and little-known species. Zootaxa 4756(1), zootaxa-4756. https://doi. org/10.11646/zootaxa.4756.1.1

Lima, L. R. C., Mariano, R., Pinheiro, U., 2013. New species for Thraulodes Ulmer, 1920 (Ephemeroptera: Leptophlebiidae: Atalophlebiinae) and the first key to adults from Brazil. Zootaxa 3709 (3), 230-242. https://doi.org/10.11646/zootaxa.3709.3.2.

Mariano, R., Flowers, R. W., Froehlich, C. G., 2011. Four new species, a new synonymy and new record for Thraulodes Ulmer 1920 (Ephemeroptera: Leptophlebiidae: Atalophlebiinae). Ann. Limnol. - Int. J. Lim. 47, 387-393. https://doi.org/10.1051/limn/2011044.

McCafferty, W. P., 1998. Ephemeroptera and the great American interchange. J. N. Am. Benthol. Soc. 17, 1-20. https://doi.org/10.2307/1468048.

Medina, B. Y. B., Pérez, B. Y., 2010. Thraulodes eduardorum(Ephemeroptera: Leptophlebiidae) nueva especie para Venezuela. Entomotrópica $25,49-62$. 
Needham, J. G., Murphy, H. E., 1924. Moscas de mayo neotropicales. Boletín de la Biblioteca Lloyd Número 24. Ser. Entomol. 4, 1-79.

Peckarsky, B. L., McIntosh, A. R., Caudill, C. C., Dahl, J., 2002. Swarming and mating behavior of a mayfly Baetis bicaudatus suggest stabilizing selection for male body size. Behav. Ecol. Sociobiol. 51, 530-537. https://doi.org/10.1007/s00265-002-0471-5.

Pérez, B., Nieto, L., 2016. Nuevos registros de Thraulodes eduardorum Medina y Pérez, 2010 (Ephemeroptera: Leptophlebiidae: Atalophlebiinae) para los estados Carabobo y Yaracuy, Venezuela. Entomotrópica 31 (7), 54-59.

Pérez, G. B., Liria, J., Leal, S. R., Nieto, C. L., Guerrero, D. E., 2020. Thraulodes marreroiChacón, Segnini y Domínguez (Ephemeroptera: Leptophlebiidae: Atalophlebiinae): nuevos registros para Venezuela y un análisis sobre su distribución neotropical mediante el modelo de nicho ecológico. Rev. Chil. Entomol. 46 (3), 509-520. https://doi. org/10.35249/rche.46.3.20.17.

Salles, F. F., 2006. Ephemeroptera do Brasil. Available in: http:// ephemeroptera.br.googlepages.com/home (accessed 11 January 2021).
Sartori, M., Brittain, J. E., 2015. Order Ephemeroptera. In: Thorp J.H., Rogers D.C. (Eds.), Ecology and General Biology: Thorp and Covich's Freshwater Invertebrates, Elsevier Academic Press, Boston, pp. 873-891.

Soldán, T., 1979. A comparative study of spermatozoa of some central European Ephemeroptera. Acta. Entomol. Boh. 76, 223-230.

Souto, P. M., Da-Silva, E. R., Nessimian, J. L., 2014. Two new species of Thraulodes Ulmer, 1920 (Ephemeroptera: Leptophlebiidae: Atalophlebiinae) from Southeast Brazil. Zootaxa 3760 (4), 571-578. https://doi.org/10.11646/zootaxa.3760.4.6.

Traver,J. R., Edmunds Junior, G. F., 1967. A revision of the genus Thraulodes (Ephemeroptera: leptophlebiidae). Misc. Publ. Entomol. Soc. Am. 5 (8), 349-395.

Walker, F., 1853. Ephemerinae. List of the specimens of neuropterous insects in the collection of the British Museum, Part III (TermitidaeEphemeridae), London, pp. 533-585. Printed by order of the trustees.

Zúñiga, M. C., Molineri, C., Domínguez, E., Cardona, W., 2015. Leptophlebiidae (Insecta: Ephemeroptera) from Gorgona Island National Natural Park (Tropical Eastern Pacific, Colombia) with the description of two new species. Ann. Limnol. -. Int. J. Lim. 51, 281-296. https:// doi.org/10.1051/limn/2015026. 